\title{
Erratum to: Feasible Precautions in Attack and Autonomous Weapons
}

\author{
Jeffrey S. Thurnher
}

\section{Erratum to:}

Chapter 6 in: W. Heintschel von Heinegg et al. (eds.), Dehumanization of Warfare: Legal Implications of New Weapon Technologies, https://doi.org/10.1007/978-3-319-67266-3_6

This chapter was originally published under (C) Springer International Publishing AG 2017, but has now been corrected to "This is a U.S. Government work and not under copyright protection in the US; foreign copyright protection may apply" 